\section{Autoradiography of End-plates with Carbon-14 - Calabash - Curarine I and Carbon-14 - Decamethonium}

A HUNDRED years have passed since Claude Bernard's publication of his investigations on the action of curarine in "Lecons sur les effets des substances toxiques et médicamenteuses" 1 . He was able by indirect experiments to localize the curare-block in the end-plates of skeletal muscle. Some time ago when we investigated the metabolism of carbon-14 curarine $I$ in the cat ${ }^{2}$, we tried to obtain autoradiographs of muscle, intending to show the fixation of this alkaloid directly at the neuro-muscular junctions.

For this purpose we had to synthesize carbon-14 curarine of the highest possible radioactivity by methylation of $2.0 \mathrm{mgm}$. nor-curarine with an excess of $6.4 \mathrm{mgm} .{ }^{14} \mathrm{CH}_{3} \mathrm{I}$, having the activity of $1 \mathrm{mc}$. After recrystallization we obtained 0.25 mgm. pure carbon:14 - curarine - iodide (biquaternary) with an activity of $24.2 \mu \mathrm{c} . / \mathrm{mgm}$. The minimal lethal doso of the water solution was injected into the veins of the tails of mice, which died of asphyxia within 40-120 sec. The diaphragms of these animals were stretched over steel rings of the same diameter $(22 \mathrm{~mm}$.) and dried in air. They were then brought into contact with X-ray film (Ilford $\mathrm{X}$-ray $\left.P M_{1}\right)$ or mounted on microscope slides and covered by stripping film (Kodak). After developing the films the end-plates were stained by the Koelle method, in which acetylthiocholine is split by the cholinesterase, brown copper sulphide finally resulting ${ }^{3}$.

After 60 days the resulting pictures on $\mathrm{X}$-ray film showed a slight blackening in the region of the endplates, which lie in a band of $260 \mu$ thickness around the centrum tendineim. In addition, there was blackening over the centrally situated vessels due to radioactivity in the blood. On microscopic examination of the stripping film a diffuse formation of silver grains over the end-plates was seen; but the crossfire over this region had been so heavy that only twice the grain density existed over each end-plate as compared to its immediate surroundings. 'The whole region had a 4-6 times higher density of grains com.

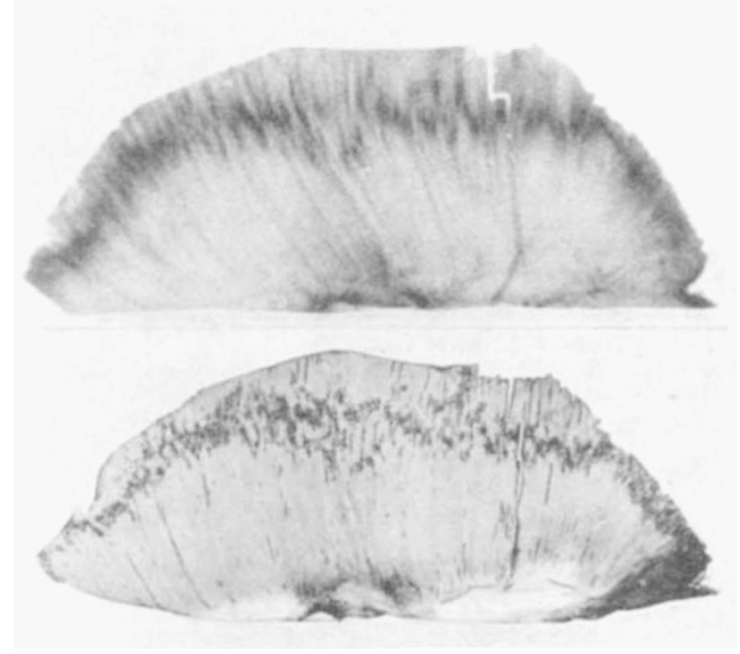

1ig. 1. Autoradiograjhy of mouse diaphragm with carbon-1.4decamethonium in comparison with staining of end-plates in the same diaphragu by the Koelle method $(x c, 4)$

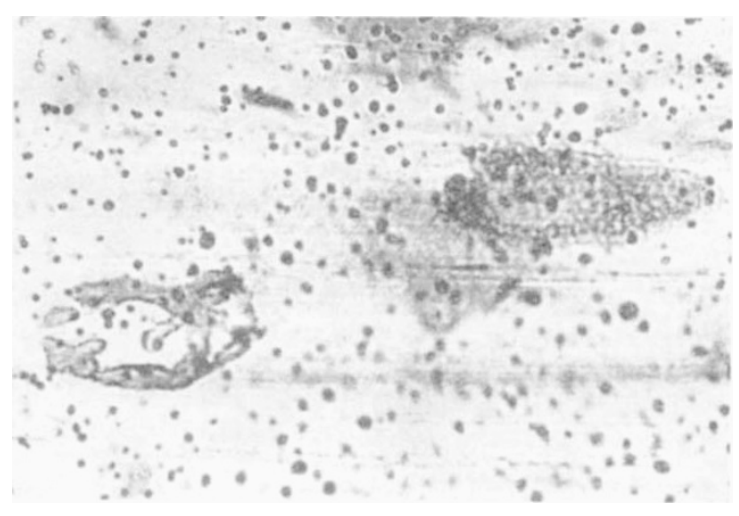

Fig. 2. stained end-plates (Koelle method, $\times$ c. 700) and silver grains in stripping fllm by carbon-14-decamethonium

pared with a corresponding region of muscle without end-plates.

In order to obtain a much higher spocific activity in a curarizing molecule we then methylated decamethylendiamine with ${ }^{1{ }^{4}} \mathrm{CH}_{3} \mathrm{I}$ and obtained 0.44 mgm. decamethonium with six carbon-14 atoms. The specific radioactivity was approximately five times larger than that of carbon-14-curarine. After five days the resulting autoradiographs again showed clearly the localization over the end-plates, especially when compared with the stained diaphragms (Fig. 1). Over this region we counted four times more silver grains in the unit area of stripping film than in the muscle layer farther out (Fig. 2).

These pictures thus prove the fixation of 'curarizing' and 'depolarizing' drugs in the end-plate. They make possible the calculation of the number of molecules reacting with the receptor surface. We found $8 \times 10^{6}$ curarine molecules bound to one end-plate and $1.7 \times 10^{12}$ molecules $/ \mathrm{cm}^{2}{ }^{2}$ of apparent area of endplate membrane, thus neglecting the possibility of a large increase in surface due to the palisade structure described by Couteaux ${ }^{4}$. The order of magnitude of apparent coverage of the end-plate surface is 5 per cent.

Details will be published in Archives internationales de Pharmacodynamie et de Thérapie.

P. G. WASER

U. I،ÜTHI

Department of Pharmacology,

University of Zurich. July 24

${ }^{1}$ Bernard, C., 238-353 (Paris, 1857).

${ }^{2}$ Waser, P., Schmid, H., and Schmid, K., Archives Internat. de Pharmacodynamie et de 'therrapie, 96, 386 (1954).

${ }^{3}$ Koelle, G. B., and Friedenwald, J. S., Proe. Soc. Exp. Biol. and Med., 70, $617(1949)$

"Coutcaux, R., Thèse de l'université de Paris : "Contribution à l'étude de la synapse myoneurale" (Montréal, 1947).

\section{Globulins in the Chicken Egg-White}

LONGSWORTH et al.' domonstrated, by electrophoresis in the Tiselius apparatus, three globulins in the white of an egg. 'These were labelled $G_{1}, G_{2}, G_{3}$. ( $G_{1}$ was identified later with the lysozyme.)

The antigenic properties of egg-globulins were demonstrated first by Hektoen and $\mathrm{Cole}^{2}$ and later by $\mathrm{me}^{3}$.

In my studies on egg-white and its constituents ${ }^{3-5}$, I have employed the methods which permit the analysis of complex mixtures, such as electrophoresis 